This Journal is available in Telkom University online Journals

Jurnal Manajemen Indonesia

\title{
Local Own Revenue, Decentralization and Local Financial Independent
}

Purnama Sari, Isep Saepul Muzaki, Nurdiana Mulyatini, Eva Faridah, and Benny Prawiranegara Fakultas Ekonomi, Universitas Galuh, Ciamis, Indonesia

\begin{abstract}
The regional autonomy system provides an opportunity for regions in the territory of Indonesia to utilize their sources of income independently so that the implementation of development in the regions does not only rely on finance from the central government. In this study, we are of the opinion that regions that are able to optimize their local own revenue will have an impact on increasing local financial independence. Local financial independence is the ability of a region to finance development in its area. Our other opinion assumes that the relationship between local own revenue and the local financial independence can be strengthened by the implementation of decentralization. With good decentralization, local governments are more transparent in providing all information to the public, can increase accountability because public services are getting closer, local governments can take strategic decisions, improve fiscal management, improve economic growth and market security. The new contribution of this study is related to the literature of the merging of the relationship between local own revenue, decentralization, and local financial independence that was built through Moderated Regression Analysis (MRA) evidence in one of the regions in Indonesia, namely Ciamis. The results of the study show that regional local own revenues influence local financial independence. Meanwhile, decentralization which is proxied using local government expenditures is able to strengthen the relationship of local own revenues to local financial independence. So it can be concluded that the effective implementation of decentralization is able to encourage an increase in regional income that comes from its own sources to realize financial independence in the region.
\end{abstract}

Keywords-Decentralization, Local Financial Independent, Local Own Revenue.

\begin{abstract}
Abstrak
Sistem otonomi daerah memberikan kesempatan kepada daerah-daerah di wilayah Indonesia untuk memanfaatkan sumber-sumber pendapatannya secara mandiri agar pelaksanaan pembangunan di daerah tidak hanya mengandalkan keuangan yang berasal dari pemerintah pusat. Dalam studi ini, kami berpendapat bahwa daerah yang mampu mengoptimalkan pendapatan asli daerahnya akan berdampak terhadap meningkatnya kemandirian keuangan daerah. Kemandirian keuangan daerah adalah kemampuan suatu daerah dalam membiayai pembangunan di daerahnya. Pendapat kami lainnya menganggap bahwa hubungan pendapatan asli daerah dengan kemandirian keuangan daerah dapat diperkuat oleh pelaksanaan desentralisasi yang baik. Dengan desentralisasi yang baik maka pemerintah daerah lebih transparan dalam memberikan semua informasi kepada publik, dapat meningkatkan akuntabilitas karena pelayanan publik menjadi lebih dekat, pemerintah daerah dapat mengambil keputusan yang strategis, meningkatkan manajemen fiscal, meningkatkan pertumbuhan ekonomi dan keamanan pasar. Kontribusi baru dari studi ini adalah menyangkut literature penggabungan hubungan antara pendapatan asli daerah, desentralisasi, dan kemandirian keuangan daerah yang dibangun melalui Moderated Regression Analysis (MRA) bukti pada salah satu daerah di Indonesia, yaitu Ciamis. Hasil studi menunjukan bahwa pendapatan asli daerah berpengaruh terhadap kemandirian keuangan daerah. Sementara itu desentralisasi yang diproksi menggunakan pengeluaran pemerintah daerah mampu memperkuat hubungan pendapatan asli daerah terhadap kemandirian keuangan daerah. Jadi dapat disimpulkan bahwa pelaksaksanaan desentralisasi yang efektif mampu mendorong peningkatan pendapatan daerah yang berasal dari sumber-sumbernya sendiri untuk mewujudkan kemandirian keuangan di daerah.
\end{abstract}

Kata kunci- Desentralisasi, Kemandirian Keuangan Daerah, Pendapatan Asli Daerah. 


\section{INTRODUCTION}

Indonesia implements a system of regional autonomy in carrying out its wheels of government. Regions are given the opportunity to be independent in running their government by exploring and utilizing existing economic resources for the prosperity and welfare of the community in the region (Darmanto, 2016; Ruliana, 2015; Mura, Buleca, Horváth, Machyniak, \& Šebík, 2014). Decentralization is expected so that an area in Indonesia can be financially independent by increasing its income. Local own revenue is considered as one indicator that can affect local financial independence (Ding, McQuoid, \& Karayalcin, 2019; Qiao, Ding, \& Liu, 2019; Siregar \& Pratiwi, 2017).

If an area can increase its local own revenue, it can be ensured that there is an increase in its local financial independence. Local financial independence means that an area does not experience financial dependence provided by the central government. This forces a region to optimize its sources of income (Erawati \& Leny, 2015; Fafurida \& Pratiwi, 2017; Tolosang, 2018). The success of development will be influenced by the level of financial independence of an area. In determining the successful implementation of the regional autonomy system, it not only involves shifting authority from the top down but must also be realized on the basis of initiatives from the bottom to encourage local financial independence (Linawati \& Suhardi, 2017; Mamogale, 2014; Nufus, Supratikta \& Muchtar, 2017; Redaputri \& Barusman, 2018; Rusmana, Putra \& Sukirman, 2015).

Decentralization which is defined as the transfer of authority granted by the central government to regional governments must be carried out on the basis of joint responsibility between institutions at the central and regional levels in accordance with the principle of subsidiarity (Sujarwoto, 2017; Rusyiana, 2017). To support the implementation of regional autonomy, a proportional, broad and accountable decentralization policy in the regions is needed which is realized from the fair regulation, distribution and utilization of national resources, and the existence of financial balance at the center and in the regions (Changwony \& Paterson, 2019; Kalamova, 2009; van der Kamp, Lorentzen, \& Mattingly, 2017).

We are interested in conducting studies in one of the regions in Indonesia, namely Ciamis. The interest is because in 2012 Ciamis had lost one of its beach tourism areas because it became one of the parts of the new autonomous region, namely Pangandaran. At least Ciamis has lost around 12 billion rupiahs annually from its income. Previously, this beach tourist attraction became one of Ciamis's biggest sources of income from local taxes, such as hotel taxes, entertainment taxes, restaurant taxes, and other sources. For this reason, Ciamis must be able to optimize its remaining sources of income in order to be able to independently carry out its development in the regions.

In this study, we are of the opinion that regions that are able to optimize their local own revenue will have an impact on increasing local financial independence. Local financial independence is the ability of a region to finance development in its area. Several studies on the relationship of local own revenue to local financial independence have been conducted (eg Erawati \& Suzan, 2015; Tolosang, 2018; Tahar \& Zakhiya, 2011; Apriana \& Suryanto, 2010; Puspitasari \& Salisa, 2017), which shows the results that there is a positive relationship between the two, the higher the local own revenue can increase its local financial independence.

Our other opinion assumes that the relationship between local own revenue and the local financial independence can be strengthened by the implementation of decentralization. The success of a region in managing its original sources of income must be supported by the success of the implementation of decentralization or governance power in the regions granted by the central government (Meliza \& Simanjuntak, 2018; Qiao et al., 2019). With good decentralization, local governments are more transparent in providing all information to the public, can increase accountability because public services are closer, local governments can take strategic decisions, improve fiscal management, improve economic growth and market security (Persson \& Tabellini, 2002; Fan et al., 2009; Ding et al., 2019; Darman, 2016).

The new contribution of this study is related to the literature of combining the relationship between local own revenue, decentralization, and the local financial independent built through Moderated Regression Analysis. Through this model, it is assumed that the implementation of high-quality decentralization will strengthen the effect of local own revenue in increasing the local financial independent, and vice versa. We build 5-year time-series data from local government financial reports. We conducted this research on one area in Indonesia, namely Ciamis. 
In the next section, we will discuss the hypotheses of this study. The third part identifies data sources, explains variables, analyzes measuring tools, and discusses empirical approaches. The fourth section reports the results of our empirical analysis, and the fifth section summarizes the conclusions drawn from this study.

\section{HYPOTHESIS DEVELOPMENT}

In this section, we discuss how the relationship between local own revenue and decentralization can increase the level of local financial independence. Some literature provides clues as to why the implementation of decentralization in a region can complement the effect of local own revenue in increasing its local financial independence. This condition was preceded by the implementation of the regional autonomy system in Indonesia in 2001, and has given a greater role to the government and regional economic actors in managing their development independently (Sari, Garvera, \& Sihabudin, 2018; Akbar, Brata, Herlina, Prawiranegara, \& Prabowo, 2019; Suci \& Asmara, 2014). This system arises due to demands from the community due to uneven development in various regions. Therefore, the system is an opportunity for the region to be able to manage its development independently, including to optimize its revenue sources (Haryanto, 2017a; Baskaran, Brender, Blesse, \& Reingewertz, 2016; Prakoso, Islami, \& Sugiharti, 2019).

To realize an independent and sustainable development, the regional government must be supported by strong finance (Kurniawan, Militina, \& Suharto, 2017; Nurulita, Arifulsyah, \& Yefni, 2018; Syamsudin, Cahya, \& Dewi, 2015; Inggrid, 2006). In order to meet development funding and governance implementation, it can be obtained from sources of local revenue (Sari, Garvera, \& Sihabudin, 2018; Akbar, Brata, Herlina, Prawiranegara, \& Prabowo, 2019). If a region can maximize its local own revenue then its dependence on finance from the center will decrease (Akbar et al., 2019; Kustianingsih, Muslimin, \& Kahar, 2018). These conditions indicate that an area will be able to finance the development and implementation of its government independently, so as to improve the quality of public services and the welfare of the people in the area (Shu, Xie, Jiang, \& Chen, 2018; Oz-Yalaman, 2019; Nur'ainy, Desfitriana , \& Utomo, 2013).

One of the advantages of decentralization is that local governments have the authority to manage finances independently (Sari et al., 2018; Sujarwoto, 2017; Kuai, Yang, Tao, Zhang, \& Khan, 2019), which among others is to explore all the resources they have to increase local revenue (Akbar et al., 2019; Lestari, Dali, \& Abdullah, 2016; Novalistia, 2016). Of course, it must be supported by the implementation of high-quality decentralization by regional leaders and their apparatus. So we argue that the implementation of high-quality decentralization will increase the effect of local own revenue in increasing its local financial independence.

Overall, all of the above statements indicate that the optimization of local own revenue will be effective in regions with high-quality decentralization implementation compared to regions with low-quality decentralization implementation to increase local financial independence. Thus the hypothesis to be tested is:

Hypothesis: High-quality decentralization will strengthen the effect of local own revenues in increasing local financial independence.

\section{RESEARCH METHODOLOGY}

\section{A. Research Design}

To test the hypothesis, we conducted an analysis using Moderated Regression Analysis to find out whether decentralization can strengthen the effect of local own revenue in increasing the local financial independence. This study is based on assumptions in developing hypotheses. If the regional government implements highquality decentralization, it will be able to strengthen the effect of local own revenue in increasing its local financial independence. Conversely, if local governments implement low-quality decentralization, it will weaken the effect of local own revenues in increasing the local financial independence.

This study was conducted in one area in Indonesia, namely Ciamis. The study was conducted on the financial condition of the area for 5 years. These data were obtained from the Budget Realization Report of the Ciamis regional government from 2014 to 2018. 


\section{B. Data}

Data included in the Moderated Regression Analysis for hypothesis testing is the realization of Ciamis's local own revenue over 5 years, as conducted by several previous studies (eg, Erawati \& Suzan, 2015; Lestari et al., 2016; Andriani \& Wahid, 2018 ). If there is an increase in local own revenue each year, it is expected that local financial independence will increase. Conversely, if there is a decline in local own revenue each year, then this condition will reduce the level of local financial independence.

Data on decentralization is represented by the realization of the budget for government spending (eg, used by Changwony \& Paterson, 2019; Kuai et al., 2019; Meliza \& Simanjuntak, 2018), assuming that government spending on low public services can force citizens to get involved in corruption in order to receive services more quickly, so that it can be predicted that a culture of corruption grows in the area, including officials who corrupt their regional income, and therefore it is certain that the implementation of decentralization in the area is of poor quality. Conversely, if government spending for public services is high it will reduce corrupt acts from citizens and officials so that it can be ensured that the implementation of decentralization in the area is of high quality (Changwony \& Paterson, 2019; Benerjee, 1990; Fisman \& Gatti, 2002). If the realization of the budget for government spending increases every year, then there is an improvement in the quality of the implementation of decentralization. Conversely, if the realization of the budget for government spending decreases every year, it shows a decrease in the quality of the implementation of decentralization.

Furthermore, data on local financial independence is represented by a percentage comparison between local own revenue and total regional revenue (eg, used by Andriani \& Wahid, 2018; Sari et al., 2018; Lestari et al., 2016; Puspitasari \& Salisa, 2017), including revenues from central government transfers given to the Ciamis government for 5 years. If the results of these comparisons increase, we can be sure that their local financial independence will increase. Conversely, if the results of the comparison decline, it can be ascertained that local financial independence is decreasing.

All data to measure decentralization, local own revenue and local financial independence were obtained from the Ciamis government budget realization report for the 2014-2018 fiscal year. Data sources and variable descriptions can be seen in the following table 1.

Table 1. Data Sources and Desciption of the Variables

\begin{tabular}{|c|c|c|c|}
\hline Variable & Definition & Year & Source \\
\hline Local Own Revenue (LOR) & $\begin{array}{l}\text { Revenues obtained from sources of income in } \\
\text { their own area. }\end{array}$ & 2014-2018 & $\begin{array}{c}\text { Ciamis Budget Realization } \\
\text { Report }\end{array}$ \\
\hline Decentralization (DEC) & $\begin{array}{l}\text { Government expenditure as a form of } \\
\text { implementation of decentralization. }\end{array}$ & 2014-2018 & $\begin{array}{c}\text { Ciamis Budget Realization } \\
\text { Report }\end{array}$ \\
\hline $\begin{array}{l}\text { Local Financial Independent } \\
\text { (LFI) }\end{array}$ & $\begin{array}{l}\text { The ability of local governments to finance } \\
\text { their own government activities, development } \\
\text { and services to the community. }\end{array}$ & 2014-2018 & $\begin{array}{c}\text { Ciamis Budget Realization } \\
\text { Report }\end{array}$ \\
\hline
\end{tabular}

\section{Empirical Approach}

In this study, we use the Moderated Regression Analysis model to test whether high-quality decentralization can strengthen the effect of local own revenue in increasing the local financial independence in Ciamis during the 2014-2018 period. To enable comparisons with previous studies that analyzed the effects of decentralization and local own revenue separately, we ran the following model:

$$
\begin{aligned}
& L F I=a+b L O R+e \\
& L F I=a+b_{1} L O R+b_{2} D E C+b_{3} L O R . D E C+e
\end{aligned}
$$

The dependent variable LFI is the level of the region's ability to run its government and development. LOR is the level of revenue derived from original sources. Furthermore, DEC which is represented by government spending shows the quality of the implementation of decentralization in an area, as used in the previous literature. 


\section{RESUlT AND DisCUSSION}

\section{A. Result}

The results of the statistical analysis of local own revenue, decentralization and the local financial independence can be described in the following table 2 .

Table 2 Descriptive Statistic

\begin{tabular}{cccccc}
\hline Var & N & Mean & Std. Dev & Min. & Max. \\
\hline LOR & 5 & 102.27 & 3.72 & 98.98 & 107.87 \\
DEC & 5 & 97.67 & 3.37 & 93.24 & 100.17 \\
LFI & 5 & 9.12 & 1.43 & 7.86 & 11.43 \\
Valid N (listwise) & 5 & & & & \\
Source: Data Processed & & & & &
\end{tabular}

Local own revenue has the lowest value of 98.98 and the highest value of 107.87 , with an average value of 102.27 and a standard deviation of 3.72. The average value shows that the local own revenue was very effectively managed by the Ciamis local government during 2014-2018 because the realization exceeded $100 \%$. Meanwhile, the implementation of decentralization which is represented by government expenditure has the lowest value of 93.24 and the highest value of 100.17, with an average value of 97.67 and a standard deviation of 3.37. The average value shows that the effective implementation of decentralization was carried out by the Ciamis local government during 2014-2018 because its realization was almost close to $100 \%$. Whereas the local financial independence has the lowest value of 7.86 and the highest value of 11.43 , with an average value of 9.12 and a standard deviation of 1.43. The average value indicates that local financial independence is at a very low level during 2014-2018 (referring to the category of financial independence developed by Fafurida \& Pratiwi, 2017).

The first step in testing the hypothesis is done with a simple regression test, to find out the relationship between the local own revenue and local financial independence. The results of the analysis in this step can be seen in the following table 3 .

Tabel 3 Simple Regression Test Results

\begin{tabular}{ccccc}
\hline \multirow{2}{*}{ Model } & $\begin{array}{c}\text { Unstandardized } \\
\text { Coefficients }\end{array}$ & $\begin{array}{c}\text { Standardized } \\
\text { Coefficients }\end{array}$ & t & Sig. \\
\cline { 2 - 3 } & $\mathrm{B}$ & Beta & & \\
\hline (Constant) & -32.062 & & & 0.006 \\
LOR & 0.403 & 0.982 & 8.940 & 0.003 \\
\hline Adjusted $R$ Square & & 0,952 & & \\
\hline Source: Data Processed & & & &
\end{tabular}

The results of this analysis explain that local own revenue can increase local financial independence. This statement was proven from the beta unstandardized coefficients which were positive at 0.403 with a significance level of 0.003 less than $\alpha=0.05$. The magnitude of the Adjusted R Square value explains that the local own revenue has an effect of $95.2 \%$ on local financial independence, while the rest is influenced by other factors not examined.

The next step in testing the hypothesis is carried out with the Moderated Regression Analysis test, to find out the extent to which decentralization is able to strengthen the effect of the relationship of local own revenue with the local financial independent. The results of the analysis in this step can be seen in the following table 4 . 
Tabel 4 Moderated Regression Analysis Test Results

\begin{tabular}{ccccc}
\hline \multirow{2}{*}{ Model } & $\begin{array}{c}\text { Unstandardized } \\
\text { Coefficients }\end{array}$ & $\begin{array}{c}\text { Standardized } \\
\text { Coefficients }\end{array}$ & & Sig. \\
\cline { 2 - 4 } & $\mathrm{B}$ & Beta & & \\
\hline (Constant) & 17.471 & & & 0.100 \\
DEC & -0.568 & -1.256 & 5.088 & 0.037 \\
LOR.DEC & 0.005 & 1.745 & 3.557 & 0.014 \\
\hline F & & 61,398 & & \\
F Sig. & & 0,016 & & \\
Adjusted $R$ Square & & 0,968 & & \\
\hline Source: Data Processed & & & &
\end{tabular}

Source: Data Processed

The results of this analysis indicate that the model used in the study is fit to be used to explain the relationship between local own revenue, decentralization and local financial independence. The statement is proven by the significance value of 0.016 less than $\alpha=0.05$. Other results show that decentralization can strengthen the effect of the relationship of local own revenue to the local financial independent because the significance value of 0.014 is smaller than $\alpha=0.05$. In addition, if you compare Adjusted R Square in the first step (see table 9) with the second step (see table 10) the value will increase by $0.016(0.968-0.952)$ or increase by $1.6 \%$. These conditions provide strong evidence that after decentralization has further strengthened the relationship between local own revenue and local financial independence.

The results of our study found that partially decentralization had a negative relationship with local financial independence because the beta unstandardized coefficients were negative at -0.568 . This is because decentralization is measured using government spending. Logically, government spending will reduce its income. Partially the relationship between decentralization and local financial independence is strengthened with a significance value of 0.037 less than $\alpha=0.05$. This means that the higher the government spending, the lower the level of local financial independence.

\section{B. Discussion}

Various literature has explained that local own revenue and decentralization as a mechanism for local financial independence. The assumption is that effective management of local own revenue can improve local financial independence, while the implementation of quality decentralization through effective policies in financial management will support the creation of local financial independence in the region so that it is able to carry out development and public services without being dependent on funds from center. As a result, it is believed that local own revenue and decentralization are supporting factors in increasing local financial independence so that local governments are able to carry out development and public services without having to wait for funding from the center. However, the two strands of literature used in this study separately document different empirical evidence. In the local own revenue literature, particularly studies relating to local government, several studies have shown that local own revenue has a positive effect on local financial independence (eg, Kustianingsih et al., 2018; Apriana \& Suryanto, 2010; Tahar \& Zakhiya, 2011; Nur'ainy et al., 2013), but other studies also provide evidence that local own revenue has a negative influence on local financial independence (eg, Lestari et al., 2016; Puspitasari \& Salisa, 2017). Likewise, there is evidence to support the argument that decentralization is a supporting factor in increasing local financial independence in the regions (eg, Syahputra, 2017; Haryanto, 2017b).

Overall, we find support for our main hypothesis that high-quality decentralization will strengthen the effect of local own revenue in increasing local financial independence. The results of our study make several contributions to the literature. First, we extend two separate strands of literature to date on the relationship between local own revenue and local financial independence and the relationship between decentralization and local financial independence. To this end, when put together in one model without conditions of interaction, we prove that local own revenue and decentralization help improve local financial independence. Second, decentralization functions as a variable to strengthen the relationship between local own revenue and local financial independence. Third, decentralization partially has a negative influence on local financial independence, because the measurement is represented by government spending so that it will reduce local own revenue which is a measure of local financial independence. 
Some literature provides explanations from various points of view regarding the relationship between local own revenue, decentralization and the local financial independence. There is a view that transfer funds from the central government reduce the motivation of local governments to increase revenues from regional potential, including local taxes (Tewodaj, Benin \& Cudjoe, 2009; Wijaya, 2019; Budiandru \& Ulhaq, 2017). Another view in an effort to increase local financial independence is determined by the existence of different levels of coercion in various regions to the public to pay taxes (Fjeldstad \& Heggstad, 2012).

In parallel, there has been a surge in empirical evidence that transfers between local governments or from the center to the regions can be explained by a number of political factors regarding regional income management policies themselves, in addition to the principles of justice and normative efficiency (Khemani, 2007, 2010; Miguel \& Zaidi, 2003; Porto \& Sanguinetti, 2001; Barkan \& Chege, 1989). These studies have found that the distribution of local government investment is able to increase local own revenue so that the region can be independent to provide public goods, which are sometimes politically motivated (Branoah, 2011; Caldeira, 2012).

Several explanations in various literature have broadened the discussion of the results of this study, so it can be concluded that the relationship of local own revenue, decentralization, and local financial independent can be explained in various perspectives, especially politics. Most of the literature on the relationship between these three variables is related to government, so the political content is very thick discussed in a variety of literature. Local tax is a potential source of regional income, which is a determining factor for local financial independence, because if a region is able to optimize its tax revenue, then financial performance in the region can be guaranteed.

\section{CONCLUSION}

We conclude that the implementation of good decentralization in a local government is very important because it will support the optimization of local own revenue to increase the local financial independent. Our results show that the regional government must utilize its authority to manage the resources in the region as the implementation of decentralization so that the region is able to increase its revenue to realize the region that is financially independent. The results support the government's commitment to creating an independent region.

However, in this study, we only examined one area through time-series data, so that the next study could conduct research in several regions with a combination of time series and cross-sectional data for the development of study results because it is possible to obtain different results.

\section{ACKNOWLEDGEMENT}

This study was supported by a grant from the Kemenristekdikti in the 2019 fiscal year. We are grateful to Galuh University for providing facilities to support this study.

\section{REFERENCES}

Akbar, D. S., Brata, Y. R., Herlina, E., Prawiranegara, B., \& Prabowo, F. H. E. (2019). Assessing Local Tax Contributions To Local Own Revenue: Evidence in One Region in Indonesia. Media Riset Akuntansi, Auditing \& Informasi, 19(1), 1-18.

Andriani, R. N. R., \& Wahid, N. N. (2018). Pengaruh Pendapatan Asli Daerah dan Dana Perimbangan Terhadap Kemandirian Keuangan Daerah (Studi Kasus Pada Pemerintah Kota Tasikmalaya Tahun 2006-2015). Jurnal Akuntansi, 13(1), 30-39.

Apriana, D., \& Suryanto, R. (2010). Analisis Hubungan antara Belanja Modal, Pendapatan Asli Daerah, Kemandirian Daerah dan Pertumbuhan Ekonomi Daerah (Studi Pada Kabupaten dan Kota se Jawa-Bali). Jurnal Akuntansi \& Investasi, 11(1), 68-79.

Baskaran, T., Brender, A., Blesse, S., \& Reingewertz, Y. (2016). Revenue decentralization, central oversight and the political budget cycle: Evidence from Israel. European Journal of Political Economy, 42, 1-16.

Banerjee, A.V. (1997). A theory of misgovernance. The Quarterly Journal of Economics, 112(4), 1289-1332.

Barkan, J. D., \& Chege, M. (1989). Decentralizing the state: District focus and the politics of reallocation in Kenya. Journal of Modern African Studies, 27(3), 431-453. 
Branoah, B. A. (2011). Do formula-based intergovernmental transfer mechanisms eliminate politically motivated targeting? Evidence from Ghana. Journal of Development Economics, 96(2), 380-390.

Budiandru \& Ulhaq, D. (2017). Penerapan Perencanaan Pajak PPH 21 Sebagai Upaya Mengefisiensikan Pajak Penghasilan Pada PT B Net Indonesia. Jurnal Manajemen Indonesia: 17(3), 219-226.

Caldeira, E., \& Rota-Graziosi, G. (2014). The crowding-in effect of simple unconditional central grants on local own-source revenue: The case of Benin. Journal of African Economics, 23(3), 361-387.

Changwony, F. K., \& Paterson, A. (2019). Accounting Practice, Fiscal Decentralization and Corruption. The British Accounting Review.

Darman. (2016). Analysis of Export-Import and Consumer Price Index in Indonesia Economic Growth. Jurnal Manajemen Indonesia, 16(1), 39-50.

Darmanto, A. (2016). Optimalisasi Sumber Pendapatan Asli Daerah Dalam Pelaksanaan Otonomi Daerah Di Kabupaten Kutai Timur. EJournal Ilmu Administrasi Bisnis, 4(1), 15-25.

Ding, Y., McQuoid, A., \& Karayalcin, C. (2019). Fiscal decentralization, fiscal reform, and economic growth in china. China Economic Review, 53, 152-167. https://doi.org/10.1016/j.chieco.2018.08.005

Erawati, N. T., \& Suzan, L. (2015). Pengaruh Pendapatan Asli Daerah Terhadap Tingkat Kemandirian Keuangan Daerah Kota Bandung. E-Proceeding of Management, 2(3), 3259-3266.

Fafurida, F., \& Pratiwi, E. N. (2017). Financial independence of regencies and cities in Central Java. Economic Journal of Emerging Markets, 9(2), 199-209.

Fan, C.S., Lin, C., \& Treisman, D. (2009). Political decentralization and corruption: Evidence from around the world. Journal of Public Economics, 93(1), 14-34.

Fisman, R., \& Gatti, R. (2002). Decentralization and corruption: evidence across countries. Journal of Public Economics, 83(3), 325-345.

Fjeldstad, O., \& Heggstad, K. (2012). Local government revenue mobilization in Anglophone Africa. CHRMichelsen Institute.

Haryanto, J. T. (2017a). Analisis Perbandingan Peta Kemampuan Keuangan Daerah Penghasil SDA dan NonSDA di Era Desentralisasi. Jurnal Ekonomi Dan Kebijakan Publik, 8(2), 103-116.

Haryanto, J. T. (2017b). the Mapping of Economics Potency and Regional Independency in Java Island During the Fiscal Desentralization Era. Journal of Indonesian Applied Economics, 7(2), 201-227.

Inggrid, I. (2006). Sektor Keuangan Dan Pertumbuhan Ekonomi Di Indonesia: Pendekatan Kausalitas Dalam Multivariate Vector Error Correction Model (VECM). Jurnal Manajemen Dan Kewirausahaan, 8(1), 4050 .

Kalamova, M. (2009). Foreign Direct Investment and Decentralization. Reflections on Fiscal Federalism: Elaborating the Research Agenda, October(30/31).

Khemani, S. (2007). Does delegation of fiscal policy to an independent agency make a difference? Evidence from intergovernmental transfers in India. Journal of Development Economics, 82(2), 464-484.

Kuai, P., Yang, S., Tao, A., Zhang, S., \& Khan, Z. D. (2019). Environmental Effects of Chinese-Style Fiscal Decentralization and the Sustainability Implications. Journal of Cleaner Production, 239(April), 1-13.

Kurniawan, A. I., Militina, T., \& Suharto, R. B. (2017). Pengaruh Investasi Swasta dan Pengeluaran Pemerintah Serta Tenaga Kerja Terhadap Pendapatan Asli Daerah dan Pertumbuhan Ekonomi. Inovasi, 13(2), 68-77.

Kustianingsih, N., Muslimin, M., \& Kahar, A. (2018). Pengaruh Pendapatan Asli Daerah (PAD), Dana Alokasi Umum (DAU), Dana Alokasi Khusus (DAK) Terhadap Tingkat Kemandirian Daerah Pada Pemerintah Daerah Kabupaten Kota di Provinsi Sulawesi Tengah. Katalogis, 6(Juni), 82-91.

Lestari, A., Dali, N., \& Abdullah, M. (2016). Pengaruh Dana Alokasi Umum (Dau) Dan Pendapatan Asli Daerah (Pad) Terhadap Belanja Modal Dan Kemandirian Keuangan Daerah Provinsi Sulawesi Tenggara. Jurnal Progres Ekonomi Pembangunan, 1(2), 44-55.

Linawati, \& Suhardi. (2017). Kemandirian dan Efektivitas Keuangan Daerah Terhadap Pertumbuhan Ekonomi di Moderasi Alokasi Belanja Modal. Ekuivalensi, 3(1), 20-28.

Mamogale, M. (2014). Financial performance of local government in Limpopo Province, 2010-2012. African Studies Quarterly, 15(1), 71-92.

Meliza, K., \& Simanjuntak, R. A. (2018). Pengaruh Desentralisasi Terhadap Masuknya Investasi Pada 32 Provinsi di Indonesia. Simposium Nasional Keuangan Negara, 1002-1019.

Miguel, E., \& Zaidi, F. (2003). Do politicians reward their supporters? Regression discontinuity evidence from Ghana. Mimeo, Berkeley: University of California.

Mura, L., Buleca, J., Horváth, P., Machyniak, J., \& Šebík, K. (2014). Identification of Funding of Regional Governments Using Correlation Analysis. Procedia Economics and Finance, 15(14), 154-161.

Novalistia, R. L. (2016). Pengaruh Pajak Daerah, Retribusi Daerah, Lain-Lain Pendapatan Asli Daerah yang Sah 
dan Bagi Hasil Pajak Terhadap Tingkat Kemandirian Keuangan Daerah Pada Pemerintah Kabupaten atau Kota di Provinsi Jawa Tengah (Studi Empiris Pada Kabupaten/Kota Provinsi Ja. Journal of Accounting, 2(2), 1-13.

Nufus, K., Supratikta, H., \& Muchtar, A. (2017). Analysis of financial performance of local government through South Tangerang calculation of realization regional budget. European Journal of Business and Management, 9(3), 136-146.

Nur'ainy, R., Desfitriana, D., \& Utomo, R. B. (2013). Pengaruh Pertumbuhan Ekonomi dan Pendapatan Asli Daerah terhadap Tingkat Kemandirian Keuangan Daerah (Studi Kasus Pada Kota Di Jawa Barat). Proceeding PESAT, 5(October), 95-104.

Nurulita, S., Arifulsyah, H., \& Yefni, Y. (2018). Analisis Pengaruh Kinerja Keuangan Daerah Terhadap Pertumbuhan Ekonomi Dan Dampaknya Terhadap Tingkat Pengangguran Di Provinsi Riau. Jurnal Benefita, 3(3), 336-356.

Oz-Yalaman, G. (2019). Financial inclusion and tax revenue. Central Bank Review, 19(3), 107-113.

Persson, T., \& Tabellini, G. (2002). Political economics: Explaining economic policy. Handbook of Public Economics, 3(Supplement C), 1549-1659

Prakoso, J. A., Islami, F. S., \& Sugiharti, R. R. (2019). Analisis Kemampuan dan Kemandirian Keuangan Daerah Terhadap Pertumbuhan Ekonomi dan Kemiskinan di Jawa Tengah. Jurnal REP (Riset Ekonomi Pembangunan), 4(1), 87-100.

Porto, A., \& Sanguinetti, P. (2001). Political determinants of intergov- ernmental grants: Evidence from Argentina. Economics and Politics 13, 237-256.

Puspitasari, A., \& Salisa, N. R. (2017). Pengaruh Kinerja Pendapatan Asli Daerah dan Dana Alokasi Umum Terhadap Kemandirian Keuangan Daerah (Studi Empiris Pada Kabupaten Se-Keresidenan Pati Tahun 2010-2016). Accounting Global Journal, 1(1), 30-41.

Qiao, M., Ding, S., \& Liu, Y. (2019). Fiscal decentralization and government size: The role of democracy. European Journal of Political Economy.

Redaputri, A.P., \& Barusman, M.Y.S. (2018). Strategi Pembangunan Perekonomian Provinsi Lampung. Jurnal Manajemen Indonesia, 18(2), 86-93.

Ruliana, T. (2015). Revenue Independence of East Kalimantan Province, Indonesian. Journal of Asian Scientific Research, 5(7), 340-348.

Rusyiana, A. (2017). Does Decentralization Good for Reducing Communal Conflict? A multilevel Analysis of Communal Conflict at Indonesia's Villages 2008 -2014. Journal of Public Administration Studies, 1(3), 25-43.

Rusmana, O., Putra, A.P.B., \& Sukirman. (2015). Kebutuhan Investor Terhadap Informasi Kinerja Pemerintah Daerah Kabupaten Banyumas Dalam Pengambilan Keputusan Investasi. Jurnal Manajemen Indonesia: 15(2), 141-156.

Sari, P., Garvera, R. R., \& Sihabudin, A. A. (2018). What is the Contribution of Local Original Revenue to Regional FInancial Independen? Journal of Public Administration Studies, 3(2), 78-81.

Shu, C., Xie, H., Jiang, J., \& Chen, Q. (2018). Is Urban Land Development Driven by Economic Development or Fiscal Revenue Stimuli in China? Land Use Policy, 77(March), 107-115.

Siregar, B., \& Pratiwi, N. (2017). the Effect of Local Government Characteristics and Financial Independence on Economic Growth and Human Development Index in Ondonesia. Jurnal Manajemen Dan Kewirausahaan, 19(2), 65-71.

Suci, S. C., \& Asmara, A. (2014). Pengaruh Kemandirian Keuangan Daerah Terhadap Pertumbuhan Ekonomi Kabupaten/Kota Provinsi Banten. Jurnal Ekonomi Dan Kebijakan Pembangunan, 3(1), 8-22.

Sujarwoto, S. (2017). Why Decentralization Works and Does Not Works? A Systematic Literatur Review. Journal of Public Administration Studies, 1(3), 1-10.

Syahputra, R. (2017). Analisis Derajat Desentralisasi atau Kemandirian Keuangan Daerah Dalam Pelaksanaan Otonomi Daerah di Aceh Tamiang. Jurnal Samudra Ekonomika, 1(1), 12-21.

Syamsudin, Cahya, B. T., \& Dewi, S. N. (2015). Pengaruh Kinerja Keuangan Terhadap Pertumbuhan Ekonomi, Pengangguran dan Kemiskinan. Jurnal Ekonomi Manajemen Sumber Daya, 17(1), 15-27.

Tahar, A., \& Zakhiya, M. (2011). Pengaruh Pendapatan Asli Daerah Dan Dana Alokasi Umum Terhadap Kemandirian Daerah Dan Pertumbuhan Ekonomi Daerah. Jurnal Akutansi Dan Investasi, 12(1), 88-99.

Tewodaj M., Benin, S., \& Cudjoe, G. (2009). Do external grants to district governments discourage ownrevenue generation? (Discussion Paper 00934). Washington, DC: IFPRI.

Tolosang, K. D. (2018). Pengaruh Pertumbuhan Ekonomi dan Pendapatan Asli Daerah Terhadap Tingkat Kemandirian Keuangan Daerah Kota Tomohon. Junral Berkala Ilmiah Efisiensi, 18(03), 79-92. 
van der Kamp, D., Lorentzen, P., \& Mattingly, D. (2017). Racing to the Bottom or to the Top? Decentralization, Revenue Pressures, and Governance Reform in China. World Development, 95(2017), 1-13.

Wijaya, S. (2019). Taxpayer Attitude on the Elimination of Tax Sanction and Taxation Awarenenss toward Taxpayer Compliance in Yogyakarta. Jurnal Manajemen Indonesia, 19(1), 71-79. 